\title{
Respiratory symptoms of an abdominal origin
}

\author{
Filipe Santos Mira, ${ }^{1}$ Jorge Mendes, ${ }^{2}$ Helena Temido, ${ }^{2}$ Elsa Gaspar ${ }^{2}$
}

'Department of Nephrology, Centro Hospitalar e Universitario de Coimbra EPE, Coimbra, Portugal

${ }^{2}$ Internal Medicine, Centro Hospitalar e Universitario de Coimbra EPE, Coimbra, Portugal

\section{Correspondence to} Dr Filipe Santos Mira, filipemira@netcabo.pt

Accepted 31 January 2018

\section{DESCRIPTION}

A 75 -year-old, fully dependent woman was sent to the emergency department due to a sudden onset of fever $\left(38^{\circ} \mathrm{C}\right)$, polypnoea and dyspnoea. The patient had a history of Parkinson's disease and vascular dementia, making it impossible to cooperate in the medical interview. She was feverish, breathing rapidly, although haemodynamically stable and with peripheral oxygen saturation of over $95 \%$. Blood tests showed increase in C-reactive protein $(8.51 \mathrm{mg} / \mathrm{dL})$, leucocytosis $\left(13 \times 10^{9} / \mathrm{L}, 67 \%\right.$ neutrophils and $23.1 \%$ lymphocytes) and slight hypokalaemia ( $3 \mathrm{mmol} / \mathrm{L})$, without respiratory insufficiency in the arterial blood. Chest X-ray showed no clear infectious consolidation.

Acute tracheobronchitis was assumed, so she was given an antibiotic and potassium chloride and was discharged. The patient returned the next day without fever but with all of the other symptoms, adding to them prostration. She was still breathing rapidly but her abdomen was larger and tympanic, with noticeable pain while it was being palpated, adding therefore an abdominal X-ray to the tests. Blood tests showed no change and both thoracic (figure 1) and abdominal X-rays (figure 2) showed intestinal and gastric dilation with gas. A nasogastric tube was inserted, draining food content, and a decompressive colonoscopy was performed which identified colic hypotonia with hard to remove faecal matter, $60 \mathrm{~cm}$ from the anal margin. The patient was admitted to the ward after being diagnosed with acute colonic pseudo-obstruction (Ogilvie syndrome). She was treated with multiple enemas and ionic correction and was discharged without symptoms.

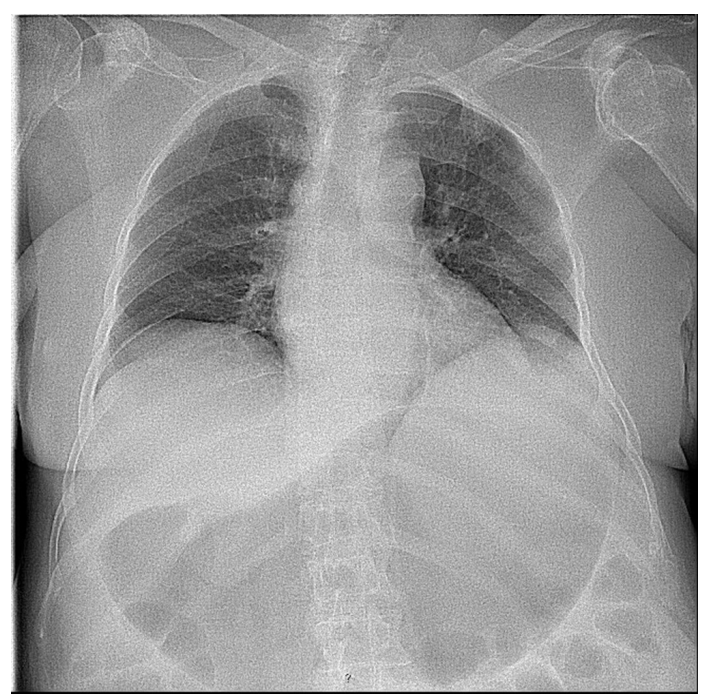

Figure 1 Chest X-ray with intestinal and gastric dilation.

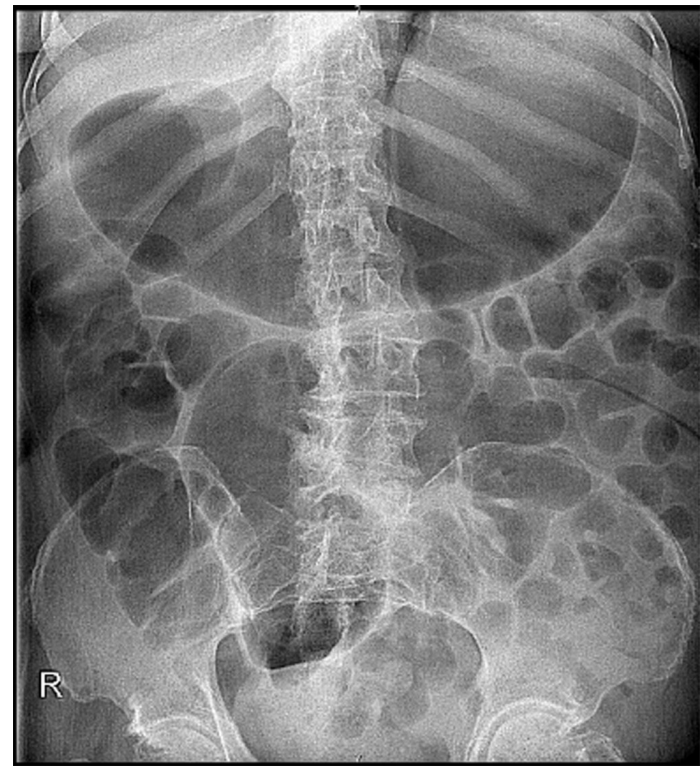

Figure 2 Abdominal X-ray with digestive tract dilation.

Acute colonic pseudo-obstruction is a rare entity with a multifactorial origin; ${ }^{12}$ in this case, possibly due to the antiparkinsonian medication, ionic unbalance and lack of movement. This is an interesting case because of the unusual presenting symptoms, as well as the image that can allow the early diagnosis and adequate treatment, avoiding complications.

\section{Learning points}

- In patients who do not cooperate with the medical interview, respiratory symptoms must not be considered carelessly and a thorough physical examination is mandatory.

- In an elderly patient, one must always consider medication as a likely cause since dopamine agonists are related to intestinal motility inhibition.

Contributors FSM wrote the article, and contributed by discussing the case and planning the treatment options as well as the most likely diagnosis. JM contributed by discussing the case, reviewing the article and aquisition of data. HT contributed by discussing the case and editing the article. EG contributed by discussing the case, adjusting the design of the article as well as reviewing it.

Competing interests None declared.

Patient consent Obtained.

Provenance and peer review Not commissioned; externally peer reviewed.

(c) BMJ Publishing Group Ltd (unless otherwise stated in the text of the article) 2018. All rights reserved. No commercial use is permitted unless otherwise expressly granted. 


\section{REFERENCES}

1 Jain A, Vargas HD. Advances and challenges in the management of acute colonic pseudo-obstruction (ogilvie syndrome). Clin Colon Rectal Surg 2012;25:037-45.
2 Wells Cl, O'Grady G, Bissett IP. Acute colonic pseudo-obstruction: A systematic review of aetiology and mechanisms. World J Gastroenterol 2017;23:5634-44.

Copyright 2018 BMJ Publishing Group. All rights reserved. For permission to reuse any of this content visit http://group.bmj.com/group/rights-licensing/permissions.

BMJ Case Report Fellows may re-use this article for personal use and teaching without any further permission.

Become a Fellow of BMJ Case Reports today and you can:

- Submit as many cases as you like

Enjoy fast sympathetic peer review and rapid publication of accepted articles

- Access all the published articles

- Re-use any of the published material for personal use and teaching without further permission

For information on Institutional Fellowships contact consortiasales@bmjgroup.com

Visit casereports.bmj.com for more articles like this and to become a Fellow 